\title{
IRISH TYPES IN OLD-TIME ENGLISH DRAMA.
}

To the circumstance that the Gael formed a not inconsiderable factor of the floating population of London in Elizabethan-Stuart days a curious passage in an old play attests. In the second part of "The Honest Whore", the action of which is laid in Milan, Lodovico expresses his surprise at seeing a humble Hibernian so far away from his native land. "An Irishman in Italy! that so strange!" retorts Astolfo, "why, the nation have running heads." 1) Lodovico takes up the theme, and adds "Marry, England they count a warm chimney corner, and there they swarm like crickets to the crevice of a brew-house." Continuing in this strain, he tells how he has laughed to see there a whole nation "marked i' th' forehead, as a man may say, with one iron; why, sir, there all costermongers are Irishmen." Yes, but not all Irish were costermongers. One finds a sportive reference in this scene, coupled with an allusion to a world renowned place of pilgrimage, to poor Dennis and his tribe figuring in London as chimney sweepers. Carolo gives as a reason for this that "Saint Patrick, you know, keeps purgatory; he makes the fire, and his countrymen could do nothing if they cannot sweep the chimneys."

1) Local colour is sadly to seek in seventeenth century dramaturgy. Where the scene is laid in Italy the action almost invariably takes place in contemporary London. Note, for example, the recurring Irish allusions in Webster's "The White Devil". In Crowne's "City Politiques" (1683), where the scene is laid in Naples, "a Foolish mistaking Irish witness" is introduced who proves a shameless, lying rogue, and talks of usquebangh as "a brave liquor tat we have in Ireland; tersh no such here; I never shaw any here". But the incongruity in this case is explained away by the fact that the play is a transparent satire on the Whig party. 
With the notable exception of Dekker no Elizabethan dramatist who attempted Hibernian portraiture had independence enough to rise superior to the popular prejudices of the time. Their attitude of cheerful hostility and frank dislike was curiously foreshadowed in "The Misfortunes of Arthur", as played at Greenwich before Queen Elizabeth on February 28, 1588. Contrasted with the character of Peace in one of the symbolical dumb shews was another "with black, long shagged haire down to his shoulders, appairled with an Irish jacket and short, having an Irish dagger in his hand". This figure, by an association of ideas, was supposed to represent "Revenge and Furie"! Here we have a splash of that tincture of thought which seems largely to have coloured the mental outlook during the first half of the seventeenth century. Of all that brilliant constellation only one dramatist saw the fair promise of Ireland, divined her gifts, sympathised with her sorrows, said a word for her in season. Let us honour Thomas Dekker for speaking out his mind. In his "Whore of Babylon" (1607) he symbolises the dead Queen, Elizabeth, as Titania, Queen of the fairies. To her come three kings on a mission, and one of them champions the cause of Ierne in the following notable words:

"You have a son,

Rebellious, wild, ingrateful, poore, and yet Apollo from's owne head cut golden lockes, To have them grow on his: his harp is his, The darts he shoots are his; the winged messenger That runnes on all the errands of the gods, Teach him swiftness; he'll outstrip the winds; This child of yours is, by adoption, Our mother's now, her blessing he receives; And tho' (as men did in the golden age), $\mathrm{He}$ live ith' open fields, hiding his head In dampish caves, and woods, (sometimes for fear), Yet do we succour him. This your lost sheep, We home again will bring, to your own fold, Humbly to graze upon your Faierie plains, Provided that you sow them with such seed, On which your whole land wholesomely may feed." 
When we desire to gain knowledge of the Elizabethan Gael it is not to Shakespeare we must turn but to Dekker and Ben Jonson. Shakespeare's one ghastly attempt at Milesian portraiture, the incomprehensible Captain MacMorris of "King Henry V.", is far from being, as intended, the common denominator of his nation. The complexities of the Gael were too subtle to be drawn slapdash by the lightning caricaturist, and the irascible MacMorris bears more resemblance to a spluttering squib than a human entity. The misfortune was that unlike the Welsh Fluellin, he was not truly observed for his own sake, nor lovingly drawn. He is merely a passing figment of the scene, brought on along with the Scottish Jamy to indicate that the nations at loggerheads in the old king's time were united under Henry at Agincourt.

If we seek a vivid picture of the old-time Gael as he appeared in the eyes of an observant and cultured Englishman we have to turn to Ben Jonson. His "Irish Masque" was first performed at court on December 29, 1613.1) "The king being set in expectation" we are told, "out ran a fellow attired like a citizen; after him three or four footmen, Dennise, Donnell, Dermock, and Patrick." Some quaint dialogue ensues. Dennis begins in asking "For Chreeshis sayk, phair ish te king? Phich ish he, ant be? show me te shweet faish quickly. By Got o' my conshence tish ish he! and tou be King Yamish, me name is Dennish, I sherve ti majesties owne cashtermonger, be me trote; and cry peepsh, and pomwatersh in to mayesties shervice, 'tis five year now. Ant tou vilt not trush me now, call up ti clarke o' ti kitchen, be ant be, shall give hish wort, upon hish book, ish true." The Donnell asks "Ish it te fashion to beate te imbasheters here, and knocke 'hem 0 ' to heads phit te phoit stick?" To which Dermot adds "ant make ter meshage run out a ter mouthsh, before tey shpeake vit te king?" The four then dispute as to who shall be spokesman to his Majesty, each striving adroitly to fasten the task upon somebody else. Dennis refuses to be persuaded. "If I speake" he says "te divell tayke

1) On January 5, 1613-4 Chamberlain wrote to Sir Dudley Carleton, "The Masque is repeated, though it is ill-timed, being in mimicry of the Irish and likely to exasperate them." 
me. I vill give tee leave to cram my mouth phit shamroke and butter and vater creeshes, instead of pearsh and peepsh." Finally Patrick assumes the position of spokesman, the others helping him out with pointed interjections. They are "good shubshects of Ireland" they protest; "of Connough, Leymster, Ulster, Munster." These "imbasheters" who have been cudgelled in mistake come to speak of "great newesh in Ireland of a great brideal of one o' ty lords here ant be", the allusion being to the marriage of Carr, Earl of Somerset. They tell of some Irish knights, who, in voyaging over to the wedding, have lost their fine clothes and are like to dance naked - clothes that cost "a towsand cowes and te prishe of a cashtell or two." We learn of the terpsichorean graces of these belated gallants who drink no bonny clabbe but right good usquebaugh. Dancing follows to the inspiring strains of the bagpipe. The footmen, in ushering in the Irish nobles, pray the king not to be angry "vit te honesh men for te few rebelsh and knavesh"; and then the quaintly heralded gallants tread a measure in their Irish mantles "to a solemn music of harps."

We get here but a momentary glimpse of Jacobean Ireland, and none other of the dramatists of the period supplement our knowledge. When they discuss the Gael at all they are content in drawing him as he appeared amidst their own surroundings, an unhappy but adaptive exile. In the pseudo-Shakespearean play called "The History of Sir John Oldcastle" there is a grim sketch of a despicable Irish lackey, "Mack Shane of Ulster" as he styles himself, who murders his young master for his chain and jewelry. He appears in the play garbed as an Englishman, having exchanged attire with another character who goes about in his "lowsie mantle" and "pair of broags". Scoundrel as he is, MacShane evinces a touch of national pride, surgings of amor patriae, in the hour of his condemnation. "Prythee, Lord Shudge" he entreats, when about to be haled off to the gallows, "let me have mine own Cloaths, my stronces there, and let me be hang'd in a Wyth after my Country the Irish fashion."

Some indirect characterisation of the itinerant fruit-sellers who perambulated London in Elizabethan times is to be found. 
in Dekker's play, "Old Fortunatus" (1600). Andelocia and his man Shadow, on their arrival in the metropolis from Cyprus, disguise themselves as Irish coster-mongers, the better to dispose of the apples of the Tree of Vice, which they cry as "feene apples of Tamasco; feene Tamasco peepins." Agripyne, attracted by the assertion that this wonderful fruit will endow a woman with irresistible beauty, is on the verge of purchasing. But a passing doubt crosses her mind, causing her to say,

\section{"These Irishmen,}

Some say, are great dissemblers, and I fear

These two the badge of their country wear."

To which Andelocia makes reply: "By my trot and by St. Patrick's hand, and as Creez save me, la 'tis no dissembler; de Irishman now and den cut di countryman's throat, but yet in fayt he love di countryman, 'tis no dissembler; dis feene Tamasco apple can make de sweet countenance, but I take no less but three crowns for one. I wear out my naked legs and my foots and my toes, and run hidder and didder to Tamasco for dem." Eventually several of the characters are induced to purchase the wonderful fruit by well assumed blarney, and as a result of their credulity are horrified to find horns sprouting out on their heads.

Principally because of their athletic prowess Irishmen were much employed in Elizabethan-Stuart times as running footmen, a capacity in which they carried their native darts for self-protection. ${ }^{1}$ ) One finds many allusions to them in the old plays, notably in Field's "Amends for Ladies" (1618), in which Lady Honour disguises herself "like an Irish footboy with a dart." The type has been finely embodied by Dekker in his characterisation of Bryan the servant in "The Honest Whore". Unlike the ruck of Elizabethan stage Irishman,

1) It is curious to learn of the great Duke of Buckingham representing the type in some aristocratic mummery acted before James I. Carleton, writing from the Hagne in 1620, says "In England all goeth prosperous and joyfully (thanks be to God) as you will guess by the merry passing of the 5th of August at Salisbury, where there was a show or play of twelve parts wherein the lord of Buckingham acted an Irish footman with all his habiliments and properties." (Calendar of State Papers, Venetian, 1620 p. 390 , note.) 
Bryan is not devoid of motherwit; and one notes a deft touch of artistic realism in the fact that in moments of emotion his tongue lapses into its original Gaelic. When Hippolito dismisses him from his service for a wholly imaginary offence there is arresting pathos in the poor man's leavetaking. "I had rather" he says, "have thee make a scabbard of my guts and let out de Irish puddings in my poor belly, den to be a false knave to de $i$ ' faat. I will never see dine own sweet face more. A mawhid deer a gra - fare dee well, fare dee well; I will go steal cows again in Ireland." The Gaelic here used was evidently "Maighisdir mo grádh", otherwise "Master of my soul".

Enough has been written to show that Dekker, had he dared to fly in the face of insular prejudice, had the capability to make the Irishman a prominent and grateful stage type. It was not, however, until the dawn of the Restoration that that consummation was brought about, and then, as it were, by accident. Sir Robert Howard in bluntly satirising the Roundheads in his comedy of "The Committee" (1662), bethought him of including among the characters a vivid presentment of a droll, faithful, simple-minded Irishman. The truth of the portraiture lay largely in the fact that it was drawn from the life and by a hand impelled by pleasing recollection. In the book entitled "Anecdotes of the Howard Family" we learn that "when Sir Robert was in Ireland, his son was imprisoned here by the Parliament for some offence committed against them. As soon as Sir Robert heard of it, he sent one of his domestics (an Irishman) to England with dispatches to his friends, in order to procure the enlargement of his son. He waited with great impatience for the return of this messenger, and when he at length appeared with the agreeable news that his son was at liberty, Sir Robert, finding that he had then been several days in Dublin, asked him the reason of his not coming to him before. The honest Hibernian answered him with great exultation that he had been all the time spreading the news, and getting drunk for joy among his friends. He, in fact, executed his business with uncommon fidelity and dispatch; but the extraordinary effect which the happy issue of his embassy had on poor Paddy was too great to suffer him to think with any degree of prudence of anything 
else. The excess of his joy was such that he forgot the impatience and anxiety of a tender parent; and until he gave all his own delight sufficient vent among all his intimates, he never thought of imparting the news where it was most wanted and desired. From this, Sir Robert took the first hint of that odd composition of fidelity and blunders which he has so humorously worked up in the character of Teague." 1 )

Although "The Committee" was far from being a brilliant comedy, the truth and excellence of this one character study kept it on the boards until the close of the eighteenth century. Many able players shone from time to time as Teague, notably Lacy (the original), Estcourt, Macklin, Isaac Sparks, Barrington and Jack Johnstone. Unfortunately the perennial vogue of Howard's droll led to the upspringing of a baneful conventionality. Instead of proceeding on parallel lines, and deriving their Milesian types from actual observation, succeeding dramatists merely copied the example. It must be said, however, in mitigation of Farquhar's reproduction of Teague in "The Twin Rivals" in 1703, that around the hem of the old chracterisation much fresh and fanciful wit was embroidered. A great traveller in his time, Teague the second is jocularly asked by his master for his opinion of London. "For dear joy" he replies "tis the bravest plaase I have sheen in my peregrinations - exshepting my nown brave shitty of CarrickVergus." Questioned as to how he intends to live at a juncture when his master has experienced a disastrous reversal of fortune, he answers, "By eating, dear joy, fen I can get it, and by sleeping fen I can get none - 'tish the fashion of Ireland". One incident is very laughable. Teague's master is cast into prison and sends the honest fellow to look up bail. While bent on his task he meets his master's flame, who is ignorant of the true state of affairs. Not desiring to be communicative, Teague tries to avoid her, but is recognised

1) Teague was the common nickname for Irishmen in the seventeenth century. Note its use by Shirley in "Hyde Park" (1632), III. 1. As a generic title it was supplanted by Paddy about the close of the eighteenth century. The phrase still survives in Ulster where it is applied by bigoted Protestants to their Roman Catholic fellow-countrymen. For Teague and his brogue, see Mr. Albert Matthews' interesting communication in The Nation (New York) of July 21, 1904. 
by the lady, who strives by walking round him to catch his eye. Finding subterfuge no longer available, the worthy fellow at last protests, "Dish ish not shivel, be me shoul, to know a shentleman fither he will or no".

Passing over Thomas Shadwell's vile caricatures of the soggarth aroon in his two political plays, "The Lancashire Witches" and "The Amorous Bigot", which, like all distortions of the sort, merely derogate from the fame of the writer, we find ourselves landed (oddly enough) at Bartholomew Fair, in London, where, in 1689, "The Royal Voyage; or The Irish Expedition" was first enacted. In this quaint tragi-comedy the epoch-marking struggle between England and the last of the Stuarts came in for ribald treatment. Endowed with a transitory background - for the scene keeps perpetually shifting from Enniskillen to Dundalk, Newry, Belfast and goodness knows where - "The Royal Voyage" is replete with" alarms and excursions", and much coarse fun is made of the cowardice and indifferent soldiering of several supposititious Hibernians. Occasionally we note a striving after local colour, as in the scene of the Irish camp, where an Irish funeral is represented with "Tapers, Crones, Dirges, and two fat friars singing and praying for his soul". 1) The friends of the departed gather round his grave, and, after tearing their hair and throwing up dirt, proceed to sing the following lament:

"Ah, brother Teague, why didst thou go?

Whililla, lilla, lilla, lilla, lilla, lilla 100 !

And leave thy friends in grief and woe,

Aboo, aboo, aboo, aboo, aboo, aboo, aboo,

Hadst thou not store of household stuff,

Whillilla, etc.,

Potatoes and Usquebagh enough!

Aboo, etc."

1) In Thomas Heywood's historical play, "The Four Prentices of London, with the Conquest of Jerusalem" (1615), a dumb shew of Irish kerns mourning a corpse in a dead march is introduced into the middle of the first act, probably with the view of emphasising the fact that the action is transpiring in Ireland. Later in the act Eustace and his trusty Irish servant are shown in Italy. 
Enough has already been said of the early stage Irishman to prove the cogency of Churchill's sentiment -

"Long, from a country ever hardly us'd, At random censur'd, wantonly abused, Have Britons drawn their sport with partial view, Form'd gen'ral notions from the rascal few;

Condemn'd a people, as for vices known, Which, from their country banish'd, seek our own." 1)

Some few years after these lines were published, Cumberland, while on a visit to his father at Kilmore, set himself to write a comedy which should redeem his countrymen from undeserved obloquy. ${ }^{2}$ ) The result was "The West Indian", a brilliant piece first produced at Drury Lane in January 1771, and assured from the outset of a long career. Viewed from an eighteenth century standpoint, it would be difficult to find a more typical or agreeable stage Irishman than Cumberland's soldier of fortune, Major Dennis O'Flagherty. Not that the character is flawless. The Major has an incorrigible propensity for widow-hunting, but his defects are smothered by a beaming good nature and a big heart. How characteristic his fire-eating attributes were is known to all readers of Sir Jonah Barrington's "Personal Sketches". He had first fought for France and Germany, then, "since the peace, my dear, I took a little turn with the confederates in Poland - but such another set of madcaps! - by the Lord Harry, I never knew what it was they were scuffling about". A very different type this from Bernard Shaw's chocolate-cream soldier!

Moody, the original Major O'Flagherty, was not a satisfactory representative. Seven or eight years later, Dublin had the advantage over the sister metropolis, for she possessed in Robert Owenson, the father of Lady Morgan, an adequate exponent of the polished Irish gentleman. Cumberland once had the good fortune to see him play Major O'Flagherty, and waited upon him after the performance to pay him a graceful compliment. "Mr. Owenson", he said, "I offer you my heartfelt congratulations. I am the first dramatist to bring an

1) Churchill's The Rosciad, ed. Lowe (1891), p. 27.

2) Cf. Richard Cumberland's Memoirs, 1807, I. 273-6 and 293 ff. 
Irish gentleman on the stage, and you are the first player to represent him like one." In his youth Robert Owenson (whose real name was MacOwen) had bi-lingual accomplishments, speaking Gaelic as freely as English. This knowledge he turned to curious advantage in playing O'Flagherty. In moments of joyous emotion he made the Major revert unconsciously to the old tongue. There was no addition to the words of the author - merely a translation of the sentiment. It is noteworthy also that "The West Indian" enjoyed the distinction of being rendered into German, and performed by a remarkable company of distinguished amateurs at Weimar on January 13, 1778. No less a personage than Goethe played Belcour, the eponymous hero of the play.

Dublin.

W. J. Lawrence. 